\title{
A experiência como recuperação do sentido da tradição em Benjamin e Gadamer
}

Roberto $\mathrm{Wu}^{*}$

\begin{abstract}
Resumo. O pensamento de Walter Benjamin é orientado pela noção de história na medida em que visa a uma implosão do conceito corrente de história como uma sucessão de fatos lineares eleitos como sendo uma "história oficial". Essa relação crítica com a história oficial envolve uma retomada produtiva do passado, da tradição, como elemento essencial da experiência histórica. Nesse sentido, a hermenêutica de Hans-Georg Gadamer também busca uma forma renovada de contato com o passado, não mais qualificada como uma reconstrução do passado, mas como uma fusão de horizontes entre presente e passado, intérprete e tradição, entre o Eu e um Tu. O artigo procura mostrar a proximidade de ambos os autores em relação ao conceito de experiência, já que, para eles, a experiência só se mostra em sua fecundidade na abertura para e na renovação da tradição.Palavras-chave: Benjamin. Gadamer. Tradição. História. Experiência.
\end{abstract}

Walter Benjamin e Hans-Georg Gadamer tiveram como uma das preocupações centrais em suas obras recuperar o sentido da tradição. Esses autores estão normalmente associados a correntes filosóficas distintas - o primeiro à tendência histórico-crítica da

* Roberto Wu é Mestre em Filosofia pela UFPR, Doutorando em Filosofia pela PUC-Rio e professor na UFPR e UNICENP.

Anos 90, Porto Alegre, v. 11, n. 19/20, p.169-198, jan./dez. 2004 
A experiência como recuperação do sentido da tradição...

da Escola de Frankfurt, e o segundo à hermenêutica filosófica. No entanto, propomos, neste texto, uma possível aproximação entre os dois pensadores através da noção de experiência, conceito-chave para o acesso à tradição. No caso de Benjamin, a genuína experiência é aquela que ocorre por meio de uma comunhão do indivíduo com a coletividade, do homem moderno com o passado. Em Gadamer, a experiência ocorre de uma maneira semelhante, embora não idêntica, à noção de fusão de horizontes. Acompanharemos inicialmente o pensamento de Benjamin, a fim de melhor caracterizarmos o conceito de experiência.

\section{Experiência e passado em Benjamin}

A experiência em Benjamin tem duas significações: a) individual, cotidiana e mais relacionada aos sentidos (Erlebnis); e b) coletiva e, nesse sentido, histórica (Erfahrung). A crítica de Benjamin é a de que, para o homem moderno, a experiência reduz-se apenas ao primeiro caso. A perda da Erfahrung, nos modernos, dá-se, entre outros fatores, pelo fetichismo da técnica, por uma nova concepção de mundo e pela caracterização do discurso como informação. ${ }^{1} \mathrm{~A}$ pobreza de experiência é caracterizada por Benjamin ao referir-se ao contexto pós-Primeira Guerra:

Não, está claro que as ações da experiência estão em baixa, e isso numa geração que entre 1914 e 1918 viveu uma das mais terríveis experiências da história. Talvez isso não seja tão estranho como parece. $\mathrm{Na}$ época, já se podia notar que os combatentes tinham voltado silenciosos do campo de batalha. Mais pobres em experiências comunicáveis, e não mais ricos. Os livros de guerra que inundaram o mercado literário nos dez anos seguintes não continham experiências transmissíveis de boca em boca. Não, o fenômeno não é estranho. Porque nunca houve experiências mais radicalmente desmoralizadas que a experiência estratégica pela guerra de trincheiras, a experiência

Anos 90, Porto Alegre, v. 11, n. 19/20, p.169-198, jan./dez. 2004 
econômica pela inflação, a experiência do corpo pela fome, a experiência moral pelos governantes. Uma geração que ainda fora à escola num bonde puxado por cavalos viu-se abandonada, sem teto, numa paisagem diferente em tudo, exceto nas nuvens, e em cujo centro, num campo de forças de correntes e explosões destruidoras, estava o frágil e minúsculo corpo humano (Benjamin, 1994a, p.114-115).

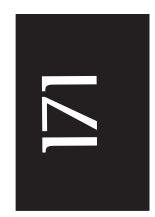

A experiência da guerra assumiu características tão monstruosas, que o repasse desse conhecimento tornava-se, de certa forma, penoso para quem o vivenciara. O nonsense pelo qual o exemplo da guerra perpassava impunha aos sobreviventes o silêncio, pois não havia nada que pudesse explicar tamanha selvageria - o uso da técnica na destruição do ser humano. A facilidade de matar que a técnica proporcionava calava os homens. Os soldados aperceberam-se, de forma muito clara, do desprezo pela vida humana, pois, ao mesmo tempo em que os mandavam para o campo de batalha, investia-se pesado no desenvolvimento e aprimoramento da indústria armamentista.

A vida humana transforma-se em mercadoria. O homem moderno é o homem do consumo, vendo assim o seu semelhante como mais uma mercadoria disponível. $\mathrm{Na}$ correnteza em que se encontra, o homem moderno tem muito pouco tempo para refletir sobre seus próprios semelhantes, assim como para pensar sobre si. A Erfahrung é, nesse sentido, um fenômeno muito raro - pois envolve a noção de coletividade. A falta de identidade do homem moderno pode ser comparada ao vidro, pois, segundo Benjamin (1994a, p.118), "não é por acaso que o vidro é um material tão duro e tão liso, no qual nada se fixa. É também um material frio e sóbrio. As coisas de vidro não têm nenhuma aura. $\mathrm{O}$ vidro é em geral o inimigo do mistério". Onde não existe mistério, não há curiosidade, o que implica que não há a disposição para experimentar o mundo do outro. Tal tema já havia sido apresentado por Baudelaire (1995a, p.34) em O Mau Vidraceiro: “[...] examinei curiosamente

Anos 90, Porto Alegre, v. 11, n. 19/20, p.169-198, jan./dez. 2004 
A experiência como recuperação do sentido da tradição...

todos os vidros e lhe disse: 'mas como? Não tem vidros de cor? Vidros cor de rosa, vermelhos, azuis, vidros mágicos, vidros do paraíso? Como é descarado! Ousa passear pelos bairros pobres sem ao menos trazer vidros que tornem a vida bela!'.". O homem moderno é caracterizado como aquele no qual não há marcas de identificação, e o vidro representa esse homem moderno, na medida em que nada se fixa nele. Em outras palavras, o homem moderno, por não possuir experiência, não pode transmiti-la, pois a Erfahrung não é experienciada pelo moderno; este só vivencia as informações, como veremos adiante.

Uma forma de retomar à Erfahrung é através do narrador, figura que vem desaparecendo:

É a experiência de que a arte de narrar está em vias de extinção. São cada vez mais raras as pessoas que sabem narrar devidamente. Quando se pede num grupo que alguém narre alguma coisa, o embaraço se generaliza. É como se estivéssemos privados de uma faculdade que nos parecia segura e inalienável: a faculdade de intercambiar experiências (Benjamin, 1994b, p.197).

O modo como o mundo contemporâneo exige as informações explica, em parte, o sumiço do narrador. As informações são as mais sucintas possíveis, o que torna rápida a absorção dos conteúdos pelo cidadão, assim como as impede de serem retidas por muito tempo. A informação é sempre algo superficial, pois trata apenas do assunto em estado bruto, numa pobreza de significações e de interpretações, enquanto que a Erfahrung requer o aprofundamento daquilo que seja dito, assim como a reflexão sobre ele e sua interpretação.

O primeiro narrador grego, segundo Benjamin, foi Heródoto. O relato que encontramos no seu Histórias foi interpretado e reinterpretado de modos diferentes ao longo do tempo. Nessa narrativa, Psammenit, o rei egípcio, havia sido derrotado pelo rei persa Cambises, que aproveitava a condição desfavorável do rei egípcio para humilhá-lo. Psammenit havia sido posto num lugar

Anos 90, Porto Alegre, v. 11, n. 19/20, p.169-198, jan./dez. 2004 
público, de modo que pudesse presenciar o desfile vitorioso dos persas. Nesse desfile, Cambises providenciou para que Psammenit pudesse ver a própria filha forçada a agir como uma criada. Psammenit permaneceu impassível durante tal acontecimento, com os olhos fixos no chão. Da mesma forma, procedeu quando viu o filho ser levado para ser executado. "Mas, quando viu um dos seus servidores, um velho miserável, na fila dos cativos, golpeou a cabeça com os punhos e mostrou os sinais do mais profundo desespero" (ibid., p.204).

Tal relato é essencialmente narrativo, na medida em que sugere uma série de interpretações. O relato compreende uma riqueza descritiva, sendo o ouvinte (no caso da tradição oral) ou o leitor obrigados a levantar uma série de questionamentos. A narrativa é deixada, de propósito, sem um fechamento, ou num modo de apresentação em que o que é dito é imediatamente assimilado. De fato, para a compreensão da narração, é necessário que o leitor ou o ouvinte passe por um processo de questionamento, pelo qual ele buscará atribuir significações para o texto. Segundo Benjamin (id.):

Essa história nos ensina o que é a verdadeira narrativa. A informação só tem valor no momento em que é nova. Ela só vive nesse momento, precisa entregar-se inteiramente a ele e sem perda de tempo tem que se explicar nele. Muito diferente é a narrativa. Ela não se entrega. Ela conserva suas forças e depois de muito tempo ainda é capaz de se desenvolver. Assim, Montaigne alude à história do rei egípcio e pergunta: por que ele só se lamenta quando reconhece o seu servidor? Sua resposta é que ele "'já estava tão cheio de tristeza, que uma gota a mais bastaria para derrubar as comportas". É a explicação de Montaigne. Mas poderíamos também dizer: "O destino da família real não afeta o rei, porque é o seu próprio destino". Ou: "muitas coisas que não nos afetam na vida nos afetam no palco, e para o rei o criado era apenas um ator".

Anos 90, Porto Alegre, v. 11, n. 19/20, p.169-198, jan./dez. 2004 
A experiência como recuperação do sentido da tradição...

Ou: "as grandes dores são contidas, e só irrompem quando ocorre uma distensão. O espetáculo do servidor foi essa distensão". Heródoto não explica nada. Seu relato é dos mais secos. Por isso, essa história do antigo Egito ainda é capaz, depois de milênios, de suscitar espanto e reflexão.

Parece que Heródoto não impunha explicação alguma para o seu leitor porque ele percebia quão importante era não fazê-lo. De fato, o evento narrado assume diferentes roupagens na medida em que é revestido de significações diversas nas várias vezes em que é relatado. Enquanto a informação visa doutrinar as pessoas, ou seja, o conteúdo transmitido é tão banal que não suscita qualquer reação de quem esteja se informando, e, por isso, o assentimento é imediato, a narração tende a apresentar algo que não é completo e que requer a ação intelectual do intérprete. De certa forma, é por isso que a narração sobrevive através dos tempos - devido à sua incompletude, à possibilidade de sempre ser renovada e encaixada em diversos contextos.

Segundo Benjamin (1994b, p.201), "o narrador retira da experiência o que ele conta: sua própria experiência ou a relatada por outros. E incorpora as coisas narradas à experiência dos seus ouvintes". O repasse das experiências é, nesse sentido, uma ligação entre o antigo e o novo. Como vimos, a informação já é, desde logo, limitada ao seu momento. A narração, entretanto, transcende o momento e ressurge de vários modos nas gerações posteriores. $\mathrm{O}$ vínculo é imediatamente estabelecido entre o narrador e os seus ouvintes ou leitores. Porém, esse vínculo remete a todos que já refletiram sobre o relato. Nesse sentido, a narração é, por excelência, uma experiência coletiva.

O inverso da experiência coletiva é apresentado por Benjamin ao referir-se ao romance. Segundo o autor (ibid., p.201),

a origem do romance é o indivíduo isolado, que não pode mais falar exemplarmente sobre suas

Anos 90, Porto Alegre, v. 11, n. 19/20, p.169-198, jan./dez. 2004 


\section{Roberto Wu}

preocupações mais importantes e que não recebe conselhos nem sabe dá-los. Escrever um romance significa, na descrição de uma vida humana, levar o incomensurável a seus últimos limites.

A incomensurabilidade a que Benjamin refere-se nada mais é do que o papel que o individualismo exerce sobre o romance, ou seja, o fato de que o romance sempre se apresenta na forma de um livro e expressa um ponto de vista particular, cujo assentimento ou não depende de cada um dos leitores. É sempre algo que remete ao individualismo, seja no momento em que é escrito, seja no momento em que é lido. "Quem escuta uma história está em companhia do narrador; mesmo quem a lê partilha dessa companhia. Mas o leitor de um romance é solitário" (ibid., p.213).

A questão sobre o caráter isolado e comunitário das experiências é retratada novamente no texto $A$ Caminho do Planetário. Nele, Benjamin escreve que "nada distingue tanto o homem antigo do moderno quanto a sua entrega a uma experiência cósmica que este último mal conhece" (Benjamin, 1987a, p.68). O homem moderno só conhece a Erlebnis, a experiência instantânea ligada às sensações e, por isso, individual e particular. Por outro lado, o homem antigo sabia que o seu saber não era um verdadeiro saber enquanto não houvesse se disseminado na coletividade. Assim, experiência do homem antigo possuía como característica o fato de pertencer a uma tradição, envolvendo, enquanto tal, a coletividade de todos que partilharam dessa experiência, o que a caracteriza como Erfahrung.

O homem moderno, criticado por Benjamin, nada mais é do que aquele que não realiza a Erfahrung, concentrando seus momentos de êxtase na relação puramente subjetiva e superficial das sensações. Nessa perspectiva, a experiência do moderno parece se assemelhar à superficialidade do consumismo, uma vez que não há reflexão sobre ela. Assim sendo, é possível falar-se na pobreza de experiência, na falta de qualidade do que é transmitido, como as experiências do pós-Primeira Guerra.

Anos 90, Porto Alegre, v. 11, n. 19/20, p.169-198, jan./dez. 2004 
A experiência como recuperação do sentido da tradição...

É preciso acentuar que, em Benjamin, experiência é sempre a experiência do passado, da tradição. Na medida em que a experiência (Erfahrung) foi substituída pela vivência (Erlebnis), o passado também se perdeu. O homem moderno vive apenas o tempo mecânico. ${ }^{2}$ Esse tempo mecânico caracteriza-se pela rotina instaurada pelo capitalismo, em que o homem não possui mais uma relação com o passado, pois vive alienado no agora do mundo técnico. Por isso, é necessário haver um corte na história que revitalize o passado.

O passado, entretanto, só nos chega por meio de uma recuperação positiva e apropriadora. De acordo com Leandro Konder (1999, p.105), “o passado não se entrega a nós; ele só nos envia sinais cifrados que dão conta, misteriosamente, de seus anseios de redenção. Cada geração recebe uma escassa força messiânica para perceber esses anseios do passado". Esse trabalho de recuperação do passado é comparado por Benjamin com o trabalho do colecionador, pois não se trata mais de restituir o sentido do que "realmente" ocorreu, como a corrente filosófica do historicismo pretendeu (Ranke, Dilthey), mas de tornar vivo no presente algo que o curso da história encarregou-se de soterrar. De acordo com Jeanne Marie Gagnebin (1999, p.14),

[...] a origem benjaminiana visa, portanto, mais que um projeto restaurativo ingênuo, ela é, sim, uma retomada do passado, mas ao mesmo tempo - e porque o passado enquanto passado só pode voltar numa não-identidade consigo mesmo - abertura sobre o futuro, inacabamento constitutivo.

Nesse sentido, é interessante a análise benjaminiana de um quadro de Paul Klee chamado Angelus Novus. Há um anjo de boca aberta e olhos totalmente arregalados que parece, pela posição das asas, estar se afastando do que vê. Benjamin vê esse anjo como o anjo da história, que olha assustado para o passado, ao contrário do homem que vê, nessa mesma história, um progresso. Embora esse anjo esteja virado para o passado, ele se encontra de costas para o

Anos 90, Porto Alegre, v. 11, n. 19/20, p.169-198, jan./dez. 2004 
curso do futuro. Essa é a metáfora benjaminiana da "história dos vencidos", que não pode nunca ser apreendida na descrição da "história oficial".

Benjamin dedica-se a uma concepção de história que não é mais a de um continuum, mas de uma história como ruptura. A história oficial que trabalha com o tempo linear e cronológico é o tempo da ideologia capitalista do mundo técnico, que clama, a si, um progresso. Segundo Pierre Missac (1998, p.26),

[...] contra o fluxo da história e o eterno retorno, que constituem a catástrofe, Benjamin invoca o tempo messiânico, tempo da ruptura e do Juízo Final. Para a durée, este último não impõe um fim, mas oferece uma possibilidade de interromper e de renovar o seu curso.

A figura do narrador, desse ponto de vista, evoca a imagem daquele que não se resume a transmitir a história oficial ou os fatos históricos tais como ocorreram. Com efeito, a história constitui-se a partir de uma retomada criativa em que presente e passado encontram-se. Na história narrada, tanto aquele que narra tem por função uma arte essencialmente criativa, pois há algo da sua experiência que o permite aconselhar o seu interlocutor, quanto aquele que ouve a narrativa tem que procurar por si mesmo interpretar e trazer para o seu mundo o significado da narração. É preciso notar que o significado da narração não é uma resposta no sentido usual, como um fechamento do texto; é antes uma procura, assim como o conselho do narrador não se consiste numa resposta, mas em um apontar para possibilidades. De acordo com Benjamin (1994b, p.200), "aconselhar é menos responder a uma pergunta que fazer uma sugestão sobre a continuação de uma história que está sendo narrada". A participação na narrativa é a reinserção do ouvinte ou do leitor no fluxo da tradição, pois ele mesmo procura sentidos na narrativa, como a tradição já procurou. Nessa direção, o trabalho do intérprete, que é sempre uma tarefa histórica, consiste 
A experiência como recuperação do sentido da tradição...

na percepção do tema que motiva a narração, esta revitalizada pelo intérprete enquanto aquele que caminha rumo à tradição e ao nãodito da tradição.

Veremos, a seguir, que esse processo de revitalização do passado, sabendo que o passado não é só aquele consagrado pela história oficial, é também o trabalho da experiência hermenêutica de Gadamer. Igualmente Gadamer pensa a compreensão e a interpretação como tarefas históricas, como uma apreensão "prática" da pergunta à qual a tradição procurou responder. A primazia da pergunta em relação à resposta subjaz tanto ao pensamento de Benjamin quanto ao de Gadamer, na medida em o legado da tradição só pode ser assumido como tal se o intérprete, no seu presente, colocar-se a caminho da questão fundamental da tradição.

\section{Experiência e tradição em Gadamer}

$\mathrm{Na}$ hermenêutica gadameriana, a autoridade da tradição não se resume apenas à sua face visível, ou seja, a essa ou àquela figura histórica, mas remete a um todo histórico que não é passível de ser esgotado pontualmente. ${ }^{3}$ Assim, Gadamer (1991, p.348) afirma que

[...] o que é consagrado pela tradição e pela herança histórica possui uma autoridade que se tornou anônima, e nosso ser histórico e finito está determinado pelo fato de que a autoridade do que foi transmitido, e não só o que se aceita razoavelmente, tem poder sobre nossa ação e sobre nosso comportamento.

Essa afirmação mostra como a autoridade da tradição não é apenas algo que depende de um consentimento racional sobre ela, pois a sua validade não se restringe apenas ao plano da razão ou dos argumentos. Não é apenas pela análise e verificação dos seus fundamentos que se decide ou não pela validade da tradição. Gadamer (1990, p.285) justamente define a tradição como "o que

Anos 90, Porto Alegre, v. 11, n. 19/20, p.169-198, jan./dez. 2004 
tem validade sem fundamentação", ou seja, independentemente das deliberações da razão, a tradição continua atuando.

Essa atuação não envolve apenas a manutenção do que correntemente seja consagrado como a tradição, mas, também, qualquer alternativa que tenha como objetivo renegar a própria tradição. O confronto com a tradição não é, de modo algum, um desvencilhar-se da tradição. Pelo contrário, tanto no confronto quanto no consentimento àquilo consagrado pela tradição, ocorre o que Gadamer chama de "adesão à tradição". Essa questão surge, por exemplo, no debate com Habermas e Giegel, no seu texto Réplica

\section{a Hermenêutica e crítica da ideologia:}

É evidente que a expressão que utilizo às vezes, dizendo que convém aderir-se à tradição, se presta a mal-entendidos. Não se trata de modo algum de privilegiar o tradicional, submetendo-se cegamente ao seu poder. A expressão "adesão à tradição" significa que esta não se esgota no que se sabe da própria origem e por isso não se pode eliminar mediante uma consciência histórica adequada. A mudança do existente é uma forma de adesão à tradição tanto quanto a defesa do estabelecido (Gadamer, 1992a, p.259).

A expressão "adesão à tradição" não é, portanto, uma submissão ao que tradicionalmente foi consagrado, mas uma partilha (que não é apenas do âmbito da razão) dos preconceitos da própria tradição. Nesse sentido, não se trata de uma renúncia à própria razão, mas da compreensão da situação hermenêutica.

Ao mesmo tempo em que a tradição faz-se visível, explicitandose por meio de teorias e autores, a tradição também recolhe-se, na medida em que o intérprete não percebe todas as nuanças de seu envolvimento com ela. Pensar a tradição como algo de que seja possível desvencilhar-se numa decisão racional, como pensou o Iluminismo, é deter-se apenas sobre o seu aspecto visível. Tal

Anos 90, Porto Alegre, v. 11, n. 19/20, p.169-198, jan./dez. 2004 
A experiência como recuperação do sentido da tradição...

entendimento da tradição ignora a sutileza pela qual ela se mantém. Embora, sob certo ponto de vista, o intérprete detenha-se em aspectos visíveis da tradição e, nesse sentido, possa dialogar e confrontar-se com ela, sob outra perspectiva, percebe-se que existe um aspecto da tradição que é anônimo. Richard Palmer (1969, p.180) comenta esse aspecto menos visível da tradição da seguinte forma: "a tradição não se coloca, pois, contra nós; ela é algo em que nos situamos e pelo qual existimos; em grande parte é um meio tão transparente que nos é invisível - tão invisível como a água o é para o peixe”. Dois aspectos são reforçados nesse comentário: o primeiro é o fato de que nós sempre já nos relacionamos com a tradição; denominaremos, pois, essa relação de pertença. O segundo aspecto é o de que, por estarmos numa relação de pertença com a tradição, o que significa estarmos situados sempre no interior dela, não há uma percepção clara sobre o papel que a tradição desempenha, tamanha é sua proximidade conosco. É nesse sentido que se disse que a autoridade da tradição tem um caráter anônimo, pois a sua atuação não se esgota numa ou noutra pessoa em específico, mas num todo histórico que não tem um rosto ou um nome. Por ser um "meio transparente e invisível", a tradição não é facilmente detectada em seu ser.

Uma maneira de se compreender como se opera essa invisibilidade inerente ao modo como a tradição exerce a sua autoridade é verificar-se a sua situação em frente ao novo. De acordo com Gadamer (1991, p.349), o que caracteriza a tradição enquanto tal é o caráter de se conservar em face das mudanças históricas: “a tradição é essencialmente conservação, e como tal nunca deixa de estar presente nas mudanças históricas". Gadamer enfatiza que a própria "ruptura" assinala, ela mesma, uma continuidade da tradição. O autor desenvolve esse argumento partindo daquilo que foi referido como a invisibilidade da tradição - ou seja, do seu modo de determinação, que é anônimo e que, portanto, não atrai atenção sobre si - a fim de mostrar como esse modo de ser acaba se integrando com o próprio processo de transformação da tradição, conservandose:

Anos 90, Porto Alegre, v. 11, n. 19/20, p.169-198, jan./dez. 2004 


\section{Roberto $\mathrm{Wu}$}

[...] a conservação é um ato da razão, ainda que caracterizado pelo fato de não atrair a atenção sobre si. Essa é a razão pela qual as inovações, os novos planos, sejam o que aparece como única ação e resultado da razão. Mas isto é assim apenas aparentemente. Inclusive quando a vida sofre suas transformações mais tumultuosas, como ocorre em tempos revolucionários, em meio à aparente mudança de todas as coisas conserva-se muito mais daquilo que era antigo do que se poderia crer, integrando-se com o novo numa nova forma de validez. Em todo caso, a conservação representa uma conduta tão livre como a transformação e a inovação. A crítica iluminista à tradição, assim como sua reabilitação romântica, ficam muito aquém do seu verdadeiro ser histórico (Gadamer, 1991, p.349-350).

A tradição conserva-se em meio às "transformações mais tumultuosas", de maneira que o novo, ou aquilo que se pretenda revolucionário, ainda é um passo da própria tradição que se organiza e se perpetua mesmo no que aparece como o mais inovador. $\mathrm{O}$ conceito de pertença a que nos referimos anteriormente encontra aqui a sua expressão máxima, ou seja, no próprio confrontar-se contra a tradição, já há a partilha de preconceitos comuns que ligam a ela os que pretendam negá-la. Segundo Palmer (1969, p.186),

[...] dentro ou fora das ciências não pode haver compreensão sem pressupostos. De onde nos vêm os pressupostos? Da tradição em que nos inserimos. Essa tradição não se coloca contra o nosso pensamento como um objeto de pensamento; antes é produto de relações, é o horizonte no interior do qual pensamos.

Nesse sentido, a afirmação de Gadamer (1992a, p.259), de que "a tradição só é ela mesma no constante tornar-se outra", mostrase fecunda para caracterizar como as transformações, revoluções ou

Anos 90, Porto Alegre, v. 11, n. 19/20, p.169-198, jan./dez. 2004 
A experiência como recuperação do sentido da tradição...

rupturas são, ainda, um desenvolvimento da própria tradição, pois a tradição não é algo estático sobre o qual seja possível se referir objetivamente. Encontramo-nos, por um lado, como que "banhados" por ela (na metáfora de Palmer) ou, como afirma o próprio Gadamer (1991, p.343), “estamos constantemente na tradição", o que significa que sempre já se transita por meio dela. Por outro lado, Gadamer também diz que o intérprete é "interpelado pela tradição mesma" (ibid., p.350). Isso visa mostrar que a tradição vem ao encontro do intérprete como um todo remissivo, sobre o qual o que se investiga mostra-se em suas significações. Nesse sentido, Gadamer indaga: "pois não é certo que só assim resultam compreensíveis em seu significado os objetos de sua investigação, assim como os conteúdos da tradição?” (id.). O próprio esclarecerse sobre o objeto de investigação traz consigo a tradição, pois é por meio dela que o objeto investigado é compreendido em seu significado, na medida em que o termo "interpelado" parece sugerir que há a necessidade de uma resposta. Logo, há uma espécie de exigência de uma tomada de decisão sobre essa interpelação, o que indica um posicionamento com relação a quem interpela, isto é, a tradição.

O passado, nesse sentido, não é algo a ser retomado "de fora", como se o intérprete já não participasse dele, pois, de acordo com Palmer (1969, p.180), "a hermenêutica de Gadamer e a sua crítica à consciência histórica sustentam que o passado não é como um amontoado de fatos que se possam tornar objeto de consciência; é antes um fluxo em que nos movemos e participamos, em todo ato de compreensão". O passado não é algo distante, mas "presente" em cada interpretação e compreensão. Essa relação com o passado é a ponte que permite compreender-se a atuação da tradição, não mais como um momento velho e estéril, o qual pode ser deixado de lado, mas como aquilo que está presente em toda compreensão. ${ }^{4}$

A pertença a tradições esclarece-se por meio dessa análise preliminar da história. Se a tradição caracteriza-se, por um lado, pelo fato de não chamar atenção sobre si, pode-se dizer que essa peculiaridade deve-se ao seu ser histórico. Embora o intérprete seja

Anos 90, Porto Alegre, v. 11, n. 19/20, p.168-198, jan./dez. 2004 
interpelado pela tradição, a sua pertença a ela não se restringe a esse momento de interpelação. Nesse sentido, alguns aspectos da tradição não são percebidos como tradicionais porque cada um é, de alguma forma, tradição. Assim, não há um distanciamento imediato entre a tradição e o intérprete que lhe permita distinguir a tradição objetivamente e, portanto, visualizá-la como totalmente separada de si mesmo. O intérprete move-se sempre junto à tradição e, desse modo, a história encontra-se no intérprete.

No nosso comportamento com relação ao passado, que constantemente estamos confirmando, o que está em questão não é o distanciamento nem a liberdade com relação ao transmitido. Pelo contrário, encontramo-nos sempre na tradição, e este nosso estar dentro dela não é um comportamento objetivador, como se o que diz a tradição fosse pensado como estranho ou alheio; o que a tradição diz já é sempre algo próprio, exemplar e dissuasor, é um reconhecerse no qual, para nosso juízo histórico posterior, não se aprecia apenas conhecimento, mas um imperceptível ir transformando-se da tradição (Gadamer, 1991, p.350).

O fato de que "nos encontramos sempre na tradição" traduzse em nos encontrarmos e nos mantermos sempre na relação com a história. O que está em jogo na relação com a tradição é o nosso próprio ser histórico, na medida em que a tradição é fonte de preconceitos, e é, portanto, para ela, que se dirigem as remissões na interpretação. A tradição faz-se presente como um passado que atua, e, por isso, o intérprete está numa relação de pertença com a tradição e com a história.

Se intérprete e tradição estão implicados numa relação de pertença, as transformações que a tradição sofre determinam, em conjunto, transformações na própria compreensão enquanto poderser do intérprete. A compreensão opera sempre a partir do estarlançado, ou seja, da facticidade, e, conjuntamente, projeta o 
A experiência como recuperação do sentido da tradição...

ser daquele que compreende para possibilidades. A facticidade fazse atuante na lida cotidiana, em que já se assumiram certos preconceitos. A tradição é, por definição, uma forma de autoridade e, portanto, de preconceitos. Assim sendo, as transformações da tradição são transformações nos preconceitos que estão envolvidos na pertença do intérprete à tradição, o que ocasiona mudanças no intérprete em relação ao seu poder-ser, às suas possibilidades, no que ele é enquanto projeção.

Essa mútua relação de efeitos é descrita por Gadamer (1991, p.351) da seguinte forma: "[...] o efeito da tradição que sobrevive e o efeito da investigação histórica formam uma unidade de efeito, cuja análise só poderia encontrar uma trama de efeitos recíprocos". O intérprete, ao tratar da tradição, está tratando de si mesmo e, inversamente, ao tratar de si, está se remetendo imediatamente à tradição. É nessa trama de efeitos recíprocos que se constitui o sentido do objeto histórico - não um objeto que renega sua própria historicidade, ou seja, um "objeto em si” remontado pelo historiador, visando a seu próprio momento histórico, mas um objeto que depende tanto da tradição na qual o objeto mostra-se significativo, quanto do intérprete e seu presente. O objeto histórico constitui-se a partir da interpelação da tradição e da resposta do intérprete à interpelação. Segundo Gadamer, o interpelar da tradição ocorre por meio de uma pluralidade de vozes, a multiplicidade de aspectos sob a qual a coisa se mostra:

Admitimos que em tempos diversos ou a partir de pontos de vista diferentes a coisa se representa historicamente sob aspectos também diversos. Aceitamos também que esses aspectos não são suspensos simplesmente na continuidade da investigação progressiva, mas que são como que condições que se excluem entre si e que existem cada qual por si próprias e que se unem somente em nós. O que satisfaz nossa consciência histórica é sempre uma pluralidade de vozes nas quais ressoa o passado. Isso somente aparece na diversidade das ditas vozes: tal

Anos 90, Porto Alegre, v. 11, n. 19/20, p.169-198, jan./dez. 2004 
é a essência da tradição da qual participamos e queremos participar. A própria investigação histórica moderna não é somente investigação, mas também mediação da tradição (Gadamer, 1991, p.352-353).

Toda investigação de um objeto histórico é também um momento da tradição. O intérprete participa da tradição ao ser interpelado pela multiplicidade de vozes que a constituem, mas também ele, o intérprete, é um momento dessa própria tradição ao procurar responder a essa diversidade de vozes. Isso é o que Gadamer (ibid., p.353) chama de "uma voz nova em que ressoa o passado".

Esse fazer-se ouvir da tradição pressupõe uma abordagem da obra, por parte do intérprete, a partir dos preconceitos não-arbitrários ou ilegítimos. Pôr os próprios preconceitos à prova é sempre uma experiência dialética e dialógica, ou seja, para que a tradição apareça em "seu sentido próprio e diferente", é necessário que o intérprete confronte seus próprios preconceitos com a tradição por meio de um questionamento. Esse questionamento não é a interrogação, por parte do intérprete, de uma totalidade fixa pertencente a um momento passado, denominada tradição, assim como, por outro lado, o intérprete também não está de posse de um outro conjunto de crenças que formariam uma realidade do presente desvinculada de um momento anterior. Nesse sentido, Gadamer comenta que "importa que nos mantenhamos longe do erro de que o que determina e limita o horizonte do presente é um acervo fixo de opiniões e valorações, e que face a isso a alteridade do passado se destaca como um fundamento sólido" (ibid., p.376).

Intérprete e tradição e presente e passado não são blocos distintos e incomunicáveis, limitados e determinados um em frente ao outro. Com a noção de história-efeitual, Gadamer mostrou que o passado e a tradição não são momentos alheios ao presente do intérprete, dado que ambos são pressupostos em cada movimento de interpretação. A história-efeitual, como pretende Gadamer, põe em questão justamente a compreensão de que tais horizontes sejam fechados em si mesmos, nas suas relações históricas contextuais. Um

Anos 90, Porto Alegre, v. 11, n. 19/20, p.169-198, jan./dez. 2004 
A experiência como recuperação do sentido da tradição...

horizonte nunca é algo fechado em si mesmo na medida em que a situação do indivíduo também é algo constantemente móvel. Segundo Gadamer (ibid., p.375), "o horizonte é, antes, algo no qual trilhamos nosso caminho e que faz conosco o caminho. O horizonte se desloca ao passo de quem se move". O horizonte transforma-se à medida que se transforma a compreensão. A compreensão é essencialmente dinâmica, pois há contínuas reformulações de conceitos; novos significados são percebidos enquanto outros se transformam. A situação do intérprete, assim como seu horizonte de interpretação, nunca é encerradas em si mesma, pois o aparato conceitual da interpretação é resultado de efeitos históricos sobre o indivíduo que interpreta. Nesse sentido, Gadamer (ibid., p.377) afirma que

o horizonte do presente não se forma, pois, à margem do passado. Nem mesmo existe um horizonte do presente por si mesmo, assim como não existem horizontes históricos a serem ganhos. Antes, compreender é sempre o processo de fusão desses horizontes presumivelmente dados por si mesmos.

A relação do intérprete com a tradição é sempre uma relação de encontro, no qual os horizontes de ambos se fundem. Como vimos anteriormente, o horizonte que resulta dessa fusão supera tanto a particularidade do intérprete quanto a da tradição, ao passar para uma "generalidade" superior. Esse horizonte é ele mesmo mutável, assim como os horizontes de onde ele procede. O que Gadamer está mostrando é o caráter dinâmico desses horizontes, na medida em que não são fechados em si mesmos e vão se formando no trabalho da interpretação. Para o Historicismo, a situação do intérprete era justamente o que impedia um olhar objetivo sobre a obra interpretada. Era necessário, portanto, reconstruir-se o momento histórico da criação da obra de um ponto de vista da própria época e, conseqüentemente, reduzirem-se, ao máximo, as interferências causadas pela situação de compreensão daquele que

Anos 90, Porto Alegre, v. 11, n. 19/20, p.169-198, jan./dez. 2004 
interpreta. Em conjunto com a idéia de se transportar à época de criação da obra e ao autor, há a pretensão de se pôr de lado tudo aquilo que não pertença ao momento de gênese da obra, incluso aí não só o que seja historicamente posterior ao seu surgimento, mas também o que seja de natureza particular, aquilo que diga respeito ao próprio intérprete. $\mathrm{O}$ sentido de deslocamento que Gadamer propõe não é, portanto, um colocar-se no lugar do outro, tal como Dilthey e Schleiermacher pensaram, mas um processo de diálogo com o outro, o que pressupõe tanto o horizonte do intérprete quanto o da tradição, fundidos num novo horizonte.

Para Gadamer, a interpretação de uma obra não se confunde com a mera exegese das intenções ou do contexto histórico de sua elaboração, mas o próprio ato de interpretar consiste no encontro da obra com a situação de quem compreende. É por meio da situação do intérprete que a obra mostra-se significativa, o que não implica mudar o foco da interpretação do autor da obra para o intérprete. Analisar a relação da obra com a situação do intérprete não consiste no privilégio de um sobre outro, mas numa dialética em que há um esclarecimento mútuo de um por meio do outro. É nesse sentido que é preciso interrogar o intérprete em sua situação.

A análise gadameriana prossegue afirmando que

[...] ter horizontes significa não estar limitado ao que há de mais próximo, mas poder ver para além disso. Aquele que tem horizontes sabe valorizar corretamente o significado de todas as coisas que caem dentro deles, segundo os padrões de próximo e distante, de grande e pequeno (Gadamer, 1991, p.373).

Ter horizontes implica um poder ver que é necessário para o julgamento mais correto das coisas pertencentes ao horizonte de compreensão. Isso significa, por outro lado, que uma interpretação equivocada é um problema de horizontes. Toda interpretação em que prevaleça a arbitrariedade dos preconceitos de quem interpreta

Anos 90, Porto Alegre, v. 11, n. 19/20, p.169-198, jan./dez. 2004 
A experiência como recuperação do sentido da tradição...

é resultante de um horizonte demasiado estreito, o qual não abrange de forma adequada a obra interpretada.

Interessam a Gadamer, em específico, as conseqüências que os conceitos de situação e horizonte ocasionam na relação entre intérprete e tradição. Ao mostrar como a iluminação da situação é uma tarefa que não se pode cumprir por completo, na medida em que se está nela, Gadamer afirma que "isso vale também para a situação hermenêutica, isto é, para a situação em que nos encontramos face à tradição que queremos compreender" (ibid., p.372). Empregando o conceito genérico de situação, Gadamer aponta para a especificidade que o caracteriza no âmbito da hermenêutica, vinculando a situação hermenêutica com a tradição. Se toda compreensão deriva de uma pertença à tradição, a impossibilidade de uma iluminação ou uma clarificação definitiva da situação hermenêutica em que o intérprete se encontra é conseqüência dessa própria pertença.

Assim como a relação entre situação e tradição é indicada por Gadamer, também o conceito de horizonte é analisado no que se refere à tradição. Ao estabelecer a distinção entre aquele que possui horizontes e o que não os possui, Gadamer diz que "a elaboração da situação hermenêutica significa então a obtenção do horizonte correto para as questões que se nos colocam frente à tradição" (ibid., p.373). Se toda compreensão tem como interlocutor privilegiado a tradição, a tarefa do intérprete é encontrar o horizonte mais correto para que a tradição possa se mostrar adequadamente, o que não significa uma atitude passiva do intérprete em frente a ela.

Como vimos, os horizontes estão em constante movimento e, por isso, não podem ser limitados ou fechados em si mesmos. Segundo Gadamer, "também o horizonte do passado, do qual vive toda vida humana e que está aí sob a forma da tradição, se encontra num perpétuo movimento" (ibid., p.375). Isso significa que o passado não é um momento fixo, o qual poderia ser reconstruído metodicamente por meio de uma análise histórica. A pressuposição do que Gadamer chamou de objetivismo histórico é a de que o passado é uma realidade dada por si mesma. Isso não

Anos 90, Porto Alegre, v. 11, n. 19/20, p.169-198, jan./dez. 2004 


\section{Roberto Wu}

ocorre, pois o passado modifica-se no mesmo passo da tradição. Nesse sentido, Gadamer escreve que

[..] quando nossa consciência histórica se desloca rumo a horizontes históricos, isto não quer dizer que se translade a mundos estranhos, nos quais nada se vincula com o nosso; pelo contrário, todos eles juntos formam esse grande horizonte que se move a partir de dentro e que rodeia a profundidade histórica de nossa autoconsciência para além das fronteiras do presente (id.).

Isso significa que, contrariamente à pretensão do objetivismo histórico, o que ocorre nunca é um transladar de um horizonte presente para uma outra realidade (a de um horizonte do passado). O passado não é uma realidade totalmente alheia ao horizonte do presente de quem interpreta; pelo contrário, o intérprete já sempre se relacionou com esse passado na medida em que sofre continuamente os efeitos dele. A relação entre o intérprete e o seu transladar ou deslocamento é posta por Gadamer nos seguintes termos:

O que significa na realidade este deslocar-se? Evidentemente não será algo tão simples como "apartar o olhar de si mesmo". Evidentemente que também isso é necessário na medida em que se procura dirigir a vista realmente a uma situação diferente. Mas temos que levar a nós mesmos até essa outra situação (id.).

Assim, o intérprete nunca está fora de sua situação e de seu horizonte, de modo a vivenciar apenas o horizonte do autor. $\mathrm{Na}$ compreensão, os preconceitos do intérprete determinam em parte o que vem a ser a coisa interpretada e, por isso, nunca podem ser desprezados, muito embora esses próprios preconceitos devam ser constantemente avaliados no confronto com a coisa interpretada.

Anos 90, Porto Alegre, v. 11, n. 19/20, p.169-198, jan./dez. 2004 
A experiência como recuperação do sentido da tradição...

Logo, deslocar-se a outras situações não implica um abandono da particularidade do intérprete em frente à obra e ao autor, mas uma relação dessa particularidade com a obra, que não se dá de modo a juntar dois pólos totalmente distintos.

Para Gadamer (id.), "[...] trata-se de um único horizonte, que rodeia tudo quanto contém em si mesma a consciência histórica”, de um único horizonte formado tanto pelo intérprete quanto pela obra. Nesse único horizonte, não há a primazia do autor sobre a obra e, por isso, não há a necessidade de se reconstruir a intenção original de criação. Segundo Gadamer (id.),

[...] este deslocar-se não é nem empatia de uma individualidade na outra, nem submissão do outro sob os próprios padrões, mas significa sempre uma ascensão a uma generalidade superior, que supera tanto a particularidade própria como a do outro.

De certa forma, tanto no Romantismo quanto no Historicismo, há o pressuposto de que compreender é abandonar uma individualidade em favor de outra, no caso, a do intérprete em favor da do autor. Por outro lado, foi demonstrado anteriormente que o Romantismo tinha em comum com o Iluminismo a idéia de que os preconceitos eram o oposto da razão e que, portanto, era necessário optar-se por um deles. Gadamer mostra que não se trata de optar por um dos pólos (ou os preconceitos do intérprete, ou a intenção do autor) na compreensão, pois o horizonte compreensivo é formado por ambos. O sentido da obra não é dado apenas pelo autor, mas forma-se no encontro da obra com o intérprete. Mesmo numa interpretação dita "objetivista", a obra adquire significado graças aos preconceitos de quem interpreta, o que, como vimos, não significa o abandono da razão. $\mathrm{Na}$ análise da obra, há, por parte do intérprete, tanto o uso da razão que formula juízos a seu respeito, quanto um posicionamento sobre essa obra direcionada por preconceitos originados, entre outras fontes, também pela tradição.

Anos 90, Porto Alegre, v. 11, n. 19/20, p.169-198, jan./dez. 2004 
Se a tradição é fonte de preconceitos, por outro lado, é por meio dela que Gadamer aponta uma possível solução para a questão da legitimidade dos preconceitos. Afinal, a compreensão trata sempre do encontro entre os preconceitos do intérprete e o que é compreendido. Gadamer (1991, p.376) descreve esse momento do seguinte modo:

[...] nós já sempre estamos tomados pelas esperanças e temores do que nos é mais próximo e saímos ao encontro dos testemunhos do passado a partir dessa pré-determinação. Por isso, deve ser uma tarefa constante impedir uma assimilação precipitada do passado com as próprias expectativas de sentido.

O encontro com a tradição tem justamente a finalidade de pôr à prova os preconceitos que movem o intérprete na compreensão de algo. O que ocorre no encontro entre tradição e intérprete é denominado por Gadamer como "destaque" (Abhebung), ou seja, a colocação de algo em evidência. O que é posto em evidência são tanto os próprios preconceitos do intérprete quanto a tradição que vem ao encontro: “destacar é sempre uma relação recíproca” (id.). É no destacar que o intérprete tem que distinguir os juízos que são originários, que se confirmam no texto interpretado, daqueles juízos que são precipitados ou determinados por expectativas de sentido que são arbitrárias. A compreensão pressupõe sempre uma avaliação contínua sobre os preconceitos. Na medida em que interroga seus preconceitos, o intérprete destaca-os daquilo que a tradição diz sobre a coisa que é interpretada, ou seja, o intérprete vê a tradição em sua diferença. Gadamer escreve que "só então se chega a ouvir a tradição tal como ela pode fazer-se ouvir em seu sentido próprio e diferente" (id.).

Essa fusão de horizontes, que sempre ocorre no encontro entre intérprete e tradição, entre presente e passado, entre a obra e o hermeneuta, remonta ao conceito de experiência hegeliano. De acordo com o que foi visto anteriormente sobre a distância temporal,

Anos 90, Porto Alegre, v. 11, n. 19/20, p.169-198, jan./dez. 2004 
A experiência como recuperação do sentido da tradição...

a interpretação envolve um aspecto dialético na experiência de quem interpreta. Tanto o "sujeito" quanto o "objeto" são modificados pela experiência, ou seja, tanto o intérprete quanto a obra aparecem em um novo estágio. A fusão de horizontes é uma redescrição dessa mesma dialética do Eu e do Outro, uma vez que é justamente do encontro entre o horizonte de ambos que resulta a interpretação, a qual transforma tanto o intérprete quanto o outro, por participarem de um horizonte diferente. Portanto, a noção de fusão de horizontes, além de indicar o aspecto dialógico, segundo o qual todo aquele que compreende o faz a partir do diálogo com outros, mostra também o caráter de transformação que essa experiência dialógica ocasiona, pois tanto o intérprete quanto o outro saem modificados por essa experiência. Nesse mesmo sentido, Maria Luísa P. F. da Silva (1995, p.367) comenta que

[...] aproximar o outro, que nos fala como tu e não como isso, implica então encontrá-lo como envio, história, tradição e, por isso mesmo, distância e mistério. Importa não só considerá-lo como pessoa, ouvindo-o e não observando-o, mas também reconhecer na pessoalidade do outro o limite do eu, uma diferença, que não é, no entanto, absoluta ou puramente dada, pois é verbo, que responde e respondendo me questiona. É realmente a experiência de um aspecto da própria coisa - uma abertura que suspende o meu juízo para o referir como questão ao horizonte do possível ou comum ainda não decidido.

Logo, o outro que o intérprete encontra na tradição não é uma voz sem vida, cuja importância está soterrada em algum momento no passado, pelo contrário, é na escuta atenta da tradição que surgem as possibilidades que apenas um "eu" não conseguiria vislumbrar. O horizonte comum em que se encontram intérprete e tradição é o solo que permite a manifestação do ser da obra. Nesse sentido, a noção de fusão de horizontes, que pressupõe sempre uma abertura ao outro, parece se aproximar do conceito heideggeriano

Anos 90, Porto Alegre, v. 11, n. 19/20, p.169-198, jan./dez. 2004 
de repetição da tradição, numa apropriação do legado por meio de um diálogo com a tradição. De acordo com Joel C. Weinsheimer (1985, p.133), "que nós tenhamos algo a aprender dos clássicos em específico significa que avançar para o futuro para remediar as deficiências do presente, necessitará de uma retomada do passado". Assim, mesmo o clássico, que é aquilo que mantém o seu vigor em face das transformações, exige uma apropriação do seu legado para que seu sentido se mostre enquanto tal, abrindo novas possibilidades para o mundo do intérprete.

\section{A possibilidade da experiência da tradição}

O pensamento histórico-crítico de Benjamin e a hermenêutica gadameriana estão muito próximos no sentido de uma recuperação do passado. Em Benjamin, o passado não se apresenta de imediato, e o que se tem é uma aparência da história como progresso. Muito pelo contrário, é necessário todo um esforço reconstituinte do passado, para apreendê-lo não como ele "realmente" foi, mas no seu sentido histórico. Essa revitalização do passado, no entanto, é o mais distante do homem moderno. Para o homem do mundo técnico, falta o elo com o passado, o que se evidencia de dois modos: pela pobreza de experiência característica desse momento histórico e pela conseqüente perda da capacidade de narrar essas experiências.

Em Gadamer, o elo com o passado ou com a tradição nunca desaparece devido à facticidade. Compreender o ser é já compreender o meu próprio ser e estar inserido numa tradição. Isso poderia ser visto como uma desavença com o pensamento benjaminiano, mas só aparentemente. Gadamer mostra que a relação do intérprete com o passado nunca é a de dois mundos totalmente distintos, mas a de horizontes que se entrecruzam. A pertença à tradição estabelece justamente o fio de continuidade entre os horizontes aparentemente distantes. A partir da tradição, o intérprete encontra-se sempre numa relação de familiaridade com a coisa interpretada. Essa familiaridade faz com que o horizonte do intérprete não seja restrito a preconceitos que nada dizem da coisa interpretada, mas essa mesma familiaridade

Anos 90, Porto Alegre, v. 11, n. 19/20, p.169-198, jan./dez. 2004 
A experiência como recuperação do sentido da tradição...

implica que os preconceitos tenham sido dados, de certa maneira, pela própria tradição, a partir da qual a coisa se mostra. Há uma circularidade entre o intérprete e a obra, sendo os elos de ligação os próprios efeitos dessa obra a partir da tradição. No entanto, a pertença à tradição e a apropriação da tradição são momentos distintos no pensamento gadameriano. A tradição precisa sempre ser renovada a partir de uma escuta atenta que retome o legado fundamental do passado.

Nesse sentido, a relação com o passado pretendida por Gadamer aproxima-se bastante do pensamento benjaminiano, pois, para ambos, essa relação nunca ocorre simplesmente, mas exige uma nova forma de experiência. A experiência como vivência (Erlebnis) é rejeitada por ambos os filósofos como sendo o processo privilegiado do conhecimento histórico. Gadamer aponta os limites da filosofia de Dilthey justamente na noção de vivência, na medida em que não permite a manifestação de um sentido mais originário da história. Dilthey teria se aproximado demasiadamente das correntes que pretendiam um conhecimento histórico objetivo, não se apercebendo dos efeitos mútuos entre o passado e o presente. Para Benjamin, também a história não pode ser reduzida a um objeto. A narrativa, justamente, transcende o seu contexto histórico originário, sendo passível de inúmeras interpretações ao longo do tempo. Isso que pareceria aos olhos do historicismo uma deficiência, é, no entanto, a sua maior virtude: o fato de a história não estar morta num significado dado, devendo este sempre ser recuperado pelos indivíduos históricos.

A tradição, nesse sentido, não é um peso ou um fardo que impossibilita o acesso correto às coisas. É certo que Benjamin analisa o homem moderno num processo cada vez maior de alienação, mas esse processo de alienação deve-se tanto ao seu domínio conquistado no curso da história, quanto aos mecanismos alienantes instalados no presente. A ruptura dessa rotina alienante não se dá apenas por um pensamento crítico do seu momento histórico, mas exige, como condição necessária para se pôr a caminho de sua efetuação, um retorno positivo ao passado.

Anos 90, Porto Alegre, v. 11, n. 19/20, p.169-198, jan./dez. 2004 


\section{Roberto Wu}

Esse acesso positivo ao passado encontra-se comprometido, na análise benjaminiana, pela pobreza de experiência, característica dos tempos atuais. O ser humano do mundo técnico capitalista está enredado numa rotina alienante, que o mantém distante de qualquer ruptura com esse processo. Mesmo que se queira, por uma atitude deliberada, realizar uma experiência originária do passado, isso lhe seria muito dificultoso, pois teria que romper com o mundo da vivência com o qual está acostumado. Certamente, esse diagnóstico não implica a impossibilidade de uma relação apropriadora da tradição. O exemplo da narrativa, mesmo quando analisado do ponto de vista do seu desaparecimento acentuado na Modernidade, apresenta uma possibilidade de experiência originária. Não se trata tanto de uma volta ao passado, procurando se repetirem velhos hábitos de outras eras, mas de se conseguir enxergar, nesse exemplo, uma outra experiência que não a que se encerra no indivíduo, pois a narrativa não acarreta apenas uma certa experiência no sentido de vivência, limitada ao indivíduo, mas é sempre uma experiência coletiva com a tradição.

A experiência em Gadamer também é a experiência de um Tu. O Tu é, no mais das vezes, a tradição. Uma abertura mais originária a esse mundo do outro é apresentada por Gadamer por diferentes maneiras: diálogo, fusão de horizontes, apropriação. Esses são conceitos que se confundem e expressam sempre a concepção de que o mundo a que pertenço nunca é fechado em si mesmo, havendo sempre uma ponte com a realidade do outro. No entanto, essa relação tem que ser apropriadora, pois, no mais das vezes, o outro não me aparece como um Tu, mas como o mesmo de um Eu.

Gadamer destaca especialmente que, ao procurar alcançar o mundo do outro, a minha própria existência modifica-se. Ao retomar positivamente o passado ou a tradição, ocorre uma modificação do meu poder-ser e do projeto do meu futuro. Isso igualmente se modifica no pensamento benjaminiano, já que a narrativa que também é sempre a experiência do outro na coletividade não é o simples relato de uma individualidade, mas recupera o sentido da tradição a que a narrativa se refere. $\mathrm{Na}$ narração, novos caminhos abrem-se para aqueles que participam daquele acontecimento.

Anos 90, Porto Alegre, v. 11, n. 19/20, p.169-198, jan./dez. 2004 
A experiência como recuperação do sentido da tradição...

Nossa análise procurou apenas revelar a proximidade dos pensamentos de Benjamin e Gadamer em relação à questão da tradição e da experiência. Certamente, essa proximidade não implica uma equivalência teórica. Além da crítica à indústria cultural de massas, à alienação cada vez mais predominante no mundo da técnica e ao desprestígio do lúdico em frente a esse mundo, Benjamin analisa a história muito mais do ponto de vista da ruptura do que da continuidade. As suas famosas Teses sobre a filosofia da história visam explodir a continuidade do tempo mecânico, o tempo cronológico do mundo técnico, o tempo da alienação que se mantém na rotina do capitalismo.

Gadamer, por outro lado, não tem como tema principal a alienação, o que lhe rendeu um debate com outro representante de Frankfurt, Jürgen Habermas, visto que se preocupou mais em analisar as condições de todo o compreender. Junto com a questão da alienação, há também a crítica recorrente que interpreta o legado gadameriano como um conservadorismo histórico, na medida em que se trata sempre da continuidade da tradição. A resposta de Gadamer é a de que toda contraposição ou possível ruptura com o estabelecido surge a partir da tradição. A tradição mantém-se em meio às mudanças sempre sendo o outro. Por outro lado, Gadamer não se preocupa em estabelecer procedimentos específicos de interpretação, numa acepção crítica, denunciadora ou reveladora de ideologias, porque esse não é o sentido da hermenêutica, o que não implica necessariamente uma concordância com o estabelecido ou com as ideologias vigentes.

Toda compreensão autêntica, ou seja, aquela que se caracteriza por uma apropriação do interpretado, tem de desvelar o ser do ente interpretado, o que remete, sempre, a um diagnóstico dos termos que compõem o horizonte do outro na sua exata medida. A phronesis aristotélica é várias vezes citada por Gadamer como o referencial da compreensão, e esse saber que vê cada coisa na sua medida correta detecta não só o aspecto positivo do interpretado, mas também os seus aspectos negativos, mediante um senso crítico. A questão que surge, no entanto, é se é possível fazer-se jus ao fenômeno do novo numa hermenêutica da facticidade, tal como Gadamer a elabora.

Anos 90, Porto Alegre, v. 11, n. 19/20, p.169-198, jan./dez. 2004 


\section{Roberto $\mathrm{Wu}$}

Parece-nos muito mais provável encontrar o caminho para tal objetivo num pensamento que tenha assumido a tarefa de explodir a continuidade da história, do que no filósofo que remete sempre a ruptura à continuidade.

\section{Experience as Recovery of tradition sense in Benjamin and Gadamer}

Abstract. Walter Benjamin's thought is guided by the notion of history as it aims to implode history's usual concept as a succession of linear facts elected as the "official history". This critical relation with the official history involves a productive retrieval of past, of tradition, as the essential element of historical experience. In this sense, Hans-Georg Gadamer's hermeneutics also search a renewed contact with the past, not anymore in terms of reconstruction of the past, but as a fusion of horizons between past and present, tradition and interpreter, the Self and the Other. This article intends to show how close these philosophers concerning the concept of experience, as for them experience only shows itself useful when opened to and when it renews tradition.

Keywords: Benjamin. Gadamer. Tradition. History. Experience.

\section{Notas}

${ }^{1}$ De acordo com Konder (1999, p.83), “o nosso crítico distinguia entre duas modalidades de conhecimento, indicadas por duas palavras diversas em alemão: Erfahrung e Erlebnis. 'Erfahrung' é o conhecimento obtido através de uma experiência que se acumula, que se prolonga, que se desdobra, como numa viagem (e viajar, em alemão, é fahren); o sujeito integrado numa comunidade dispõe de critérios que lhe permitem ir sedimentando as coisas, com o tempo. 'Erlebnis' é a vivência do indivíduo privado, isolado; é a impressão forte, que precisa ser assimilada às pressas, que produz efeitos imediatos".

${ }^{2}$ Sobre esse aspecto, ver a análise de Walter Benjamin sobre a embriaguez baudelairiana em Sobre alguns temas em Baudelaire (Benjamin, 1975). Benjamin identifica, em Baudelaire, a tentativa de romper com o tempo linear, gerando a possibilidade de a Erlebnis transformar-se na Erfahrung, na ruptura que uma sensação (um perfume, por exemplo) pode realizar, levando o indivíduo à integração com um momento coletivo do passado.

${ }^{3} \mathrm{O}$ termo autoridade tem um sentido específico em Gadamer. Não tem a ver com dominação ou um cargo superior, mas com conhecimento e reconhecimento. Trata-se de reconhecer que o outro possui uma certa primazia no saber e outorgarlhe uma autoridade num determinado assunto. A tradição, nesse sentido, é uma autoridade, mas uma autoridade que exerce sua força de uma maneira quase sempre velada.

Anos 90, Porto Alegre, v. 11, n. 19/20, p.169-198, jan./dez. 2004 


\section{A experiência como recuperação do sentido da tradição...}

${ }^{4} \mathrm{Na}$ realidade, ao tratar sobre a fusão de horizontes, Gadamer (1991, p.376-377) dirá que "não existe um horizonte do presente em si mesmo", pois este está em "um constante processo de formação".

\section{Referências}

BAUDELAIRE, C. O mau vidraceiro. In: Imago, 1995a. O Spleen de Paris. Rio de Janeiro: O Spleen de Paris. Rio de Janeiro: Imago, 1995b.

BENJAMIN, W. A caminho do planetário. In. Obras escolhidas: rua de mão única. São Paulo: Brasiliense, 1987a.

Experiência e pobreza. In: arte e política. São Paulo: Brasiliense, 1994a. Obras escolbidas: magia e técnica, O narrador. In: Obras escolbidas: magia e técnica, arte e política. São Paulo: Brasiliense, 1994b. 1994c.

Obras escolbidas: magia e técnica, arte e política. São Paulo: Brasiliense, Obras escolhidas: rua de mão única. São Paulo: Brasiliense, 1987b.

Sobre alguns temas em Baudelaire. In: Textos escolbidos. São Paulo: Abril Cultural, 1975. (Os pensadores).

GADAMER, H. G. Gesammelte Werke 1. Tübingen: JCB Mohr, 1990.

GADAMER, H. G. Réplica a Hermenêtica e crítica da Ideologia. In: Verdad y método II. Salamanca: Sígueme, 1992a.

Verdad y método. Salamanca: Sígueme, 1991.

Verdad y método II. Salamanca: Sígueme, 1992b.

GAGNEBIN, Jeanne Marie. História e narração em Walter Benjamin. São Paulo: Perspectiva, 1999.

KONDER, Leandro. O marxismo da melancolia. Rio de Janeiro: Civilização Brasileira, 1999.

MISSAC, Pierre. Passagem de Walter Benjamin. São Paulo: Iluminuras, 1998.

PALMER, R. Hermenêutica. Lisboa: Edições 70, 1969.

SILVA, Maria Luísa Portocarrero Ferreira da. O preconceito em H.-G. Gadamer: sentido de uma reabilitação. Coimbra: Calouste Gulbenkian, 1995.

WEINSHEIMER, Joel. C. Gadamer's hermeneutics: a reading of Truth and Method. New Haven: Yale Univ. Press, 1985.

Anos 90, Porto Alegre, v. 11, n. 19/20, p.169-198, jan./dez. 2004 